\title{
Vagococcus elongatus sp. nov., isolated from a swine-manure storage pit
}

\author{
Paul A. Lawson, ${ }^{1}$ Enevold Falsen, ${ }^{2}$ Michael A. Cotta ${ }^{3}$ \\ and Terence R. Whitehead ${ }^{3}$ \\ ${ }^{1}$ Department of Botany and Microbiology, University of Oklahoma, Norman, OK 73019, USA \\ ${ }^{2}$ Culture Collection, Department of Clinical Bacteriology, University of Göteborg, S-41346 \\ Göteborg, Sweden \\ ${ }^{3}$ Fermentation Biotechnology Research Unit, National Center for Agricultural Utilization \\ Research, USDA, Agricultural Research Service, 1815 N. University Street, Peoria, IL 61604, \\ USA
}

A polyphasic taxonomic study was performed on an uncharacterized Gram-positive, catalasenegative, elongated coccus-shaped bacterium isolated from a swine-manure storage pit. The bacterium, designated strain PPC9 ${ }^{\top}$, was facultatively anaerobic and had a DNA G $+\mathrm{C}$ content of $44.5 \mathrm{~mol} \%$. Comparative 16S rRNA gene sequencing indicated that the bacterium represented a novel subline within the genus Vagococcus, close to but distinct from Vagococcus lutrae. Strain $\mathrm{PPC}^{\top}$ was readily distinguished from the five recognized species of the genus Vagococcus by using biochemical tests and molecular genetic analysis. Based on phylogenetic and phenotypic evidence strain $\mathrm{PPC}^{\top}$ is considered to represent a novel species of the genus Vagococcus, for which the name Vagococcus elongatus sp. nov. is proposed. The type strain is $\mathrm{PPC9}^{\top}$ $\left(=\right.$ CCUG $51432^{\top}=$ NRRL B-41357 $\left.{ }^{\top}\right)$.

The genus Vagococcus was proposed by Collins et al. (1989) to accommodate a phylogenetically distinct group of Grampositive, motile, coccus-shaped organisms that resembled lactococci in reacting with Lancefield group $\mathrm{N}$ antisera. The genus was originally monospecific, comprising the species Vagococcus fluvialis, isolated from chicken faeces and river water (Hashimoto et al., 1974). V. fluvialis has since been recovered from diverse sources, including human clinical specimens (blood, peritoneal fluid and wounds; Teixeira et al., 1997) and various domestic animals (chickens, pigs, cattle, horses and cats; Pot et al., 1994). Four further species have subsequently been assigned to the genus. Vagococcus salmoninarum has been recovered from diseased fish (e.g. Atlantic salmon, rainbow trout and brown trout with peritonitis; Schmidtke \& Carson, 1994), Vagococcus fessus (Hoyles et al., 2000) has been isolated from a seal and a harbour porpoise, Vagococcus lutrae originated from the common otter (Lawson et al., 1999) while Vagococcus carniphilus was isolated from ground beef (Shewmaker et al., 2004). Here we report the results of a polyphasic taxonomic study on a strain of a Vagococcus-like organism isolated from a swine-manure storage pit. On the basis of the findings presented we consider that this bacterium represents a novel species of the genus Vagococcus.

The GenBank/EMBL/DDBJ accession number for the 16S rRNA gene sequence of strain $\mathrm{PPC9}^{\top}$ is $\mathrm{AF} 445297$.
An unknown, elongated coccus-shaped organism, designated strain $\mathrm{PPC}^{\mathrm{T}}$, was isolated from a swine-manure storage pit. The isolate stained Gram-positive and was catalase-negative. The unidentified organism was cultured on basic media containing macrominerals, microminerals, buffers, reducing agents and other components as in the routine growth medium described by Hespell et al. (1987), with $0.2 \%$ carbohydrate added as a carbon source. All media used in these experiments were prepared anaerobically by using the method of Hungate as modified by Bryant (1972). Strain PPC9 ${ }^{\mathrm{T}}$ was characterized biochemically by using the API Rapid ID32S and API ZYM systems at $37^{\circ} \mathrm{C}$ for $4 \mathrm{~h}$ aerobically, according to the manufacturer's instructions (API bioMérieux). Determination of the DNA G+C content was carried out by thermal denaturation of chromosomal DNA by using a Beckman model DU 640 spectrophotometer equipped with a high-performance temperature controller and $T_{\mathrm{m}}$ analysis software (Johnson, 1994). 16S rRNA gene fragments were generated by PCR with universal primers $\mathrm{pA}$ (positions 8-28 according to the Escherichia coli numbering system) and $\mathrm{pH}^{*}(1542-1522)$. The amplified product was purified by using a QIAquick PCR purification kit and sequenced directly by using primers to conserved regions of the 16S rRNA gene. Sequencing was performed by using a PRISM Taq Dye Deoxy Terminator cycle sequencing kit (Applied Biosystems) and an automatic DNA sequencer (model 373A; Applied Biosystems). The closest known relatives of 
the new isolate were determined by performing database searches with the program FASTA (Pearson \& Lipman, 1985). These sequences and those of strains of related recognized species were retrieved from GenBank and aligned with the newly determined sequence by using the program SEQtools (Rasmussen, 2002). The resulting multiple sequence alignment was corrected manually with the program GeneDoc (Nicholas et al., 1997) and a phylogenetic tree was constructed according to the neighbour-joining method (Saitou \& Nei, 1987) with the programs SEQtools and TreeView (Page, 1996). The stability of the groupings was estimated by bootstrap analysis (1000 replications) with the same programs.

Cells of strain $\mathrm{PPC}^{\mathrm{T}}$ occurred in short chains and were elongated in the direction of the chain. This elongation was so pronounced that some cells gave the appearance of short, fat rods. The new isolate was facultatively anaerobic and produced lactic acid but not gas from glucose. Cells appeared to be non-motile based on a $0.4 \%$ agar tube test (Bailey \& Scott, 1974, pp. 376-377) and when observed microscopically. The organism grew optimally at $37^{\circ} \mathrm{C}$. When grown for 3 days under $\mathrm{CO}_{2}$ on trypticase soy agar supplemented with $5 \%$ defibrinated horse blood, it produced colonies that were grey, convex and approximately $0.5-2 \mathrm{~mm}$ in diameter. Growth under strictly anaerobic conditions was slower and incubation continued for 5-7 days. No haemolysis was observed. With the API Rapid ID32S system the organism was relatively inactive, producing positive reactions only for $\beta$-glucosidase (weak), $\alpha$-galactosidase and glycyl tryptophan arylamidase. All other tests were negative. With the API ZYM system the unknown organism showed weak activity for alkaline phosphatase, esterase C4 and esterase lipase C8. No other enzymic activities were detected. The DNA G $+\mathrm{C}$ content of strain $\mathrm{PPC9}^{\mathrm{T}}$ was $44.5 \mathrm{~mol} \%$.

Comparative 16S rRNA gene sequencing was performed in order to determine the phylogenetic affinities of the unknown bacterium. Searches of GenBank revealed that the 16S rRNA gene sequence of strain $\mathrm{PPC}^{\mathrm{T}}$ was phylogenetically most closely related to those of the lactic acid group of bacteria and in particular was most highly related to those of vagococci $(94.0-96.7 \%$ sequence similarity). A neighbour-joining tree depicting the phylogenetic relationships of strain $\mathrm{PPC}^{\mathrm{T}}$ is shown in Fig. 1. The treeing analysis confirmed the close association of the organism with members of the genus Vagococcus. Strain $\mathrm{PPC}^{\mathrm{T}}$ formed a distinct subline based on this comparative 16S rRNA gene sequence analysis sharing a branching node with $V$. lutrae CCUG $39187^{\mathrm{T}}(96.7 \%$ similarity). Phylogenetically, strain $\mathrm{PPC}^{\mathrm{T}}$ formed a robust cluster with the vagococci; the association was statistically significant, although sequence divergence values of approximately 4.1-6\% between the unknown bacterium and the five recognized Vagococcus species clearly demonstrate that strain $\mathrm{PPC}{ }^{\mathrm{T}}$ represents a genetically distinct species. There is no precise correlation between level of 16S rRNA gene sequence divergence and species delineation, but it is generally recognized that divergence values of $3 \%$ or more are significant (Stackebrandt \& Goebel, 1994). Support for the distinctiveness of the unknown manure bacterium was also evident from phenotypic analyses. Biochemically, the unknown species most closely resembled $V$. fessus isolated from a seal and harbour porpoise based on their shared generally unreactive biochemical properties. However, strain $\mathrm{PPC}^{\mathrm{T}}$ could be distinguished from $V$. fessus in not producing the enzymes $\alpha$-chymotrypsin or pyroglutamic acid arylamidase and by its production of $\beta$-glucosidase (weak) and $\alpha$-galactosidase. In addition to 16S rRNA gene sequence analysis data, strain $\mathrm{PPC}^{\mathrm{T}}$ could be readily distinguished from the other recognized Vagococcus species based on the traits given in Table 1. In particular, the production of API Rapid ID32S numerical profile 22000400000 served to distinguish the novel bacterium from all recognized Vagococcus species. Thus, based on the phylogenetic and phenotypic distinctiveness of strain $\mathrm{PPC}^{\mathrm{T}}$ we consider that it should be classified as representing a novel species of the genus Vagococcus, for which the name

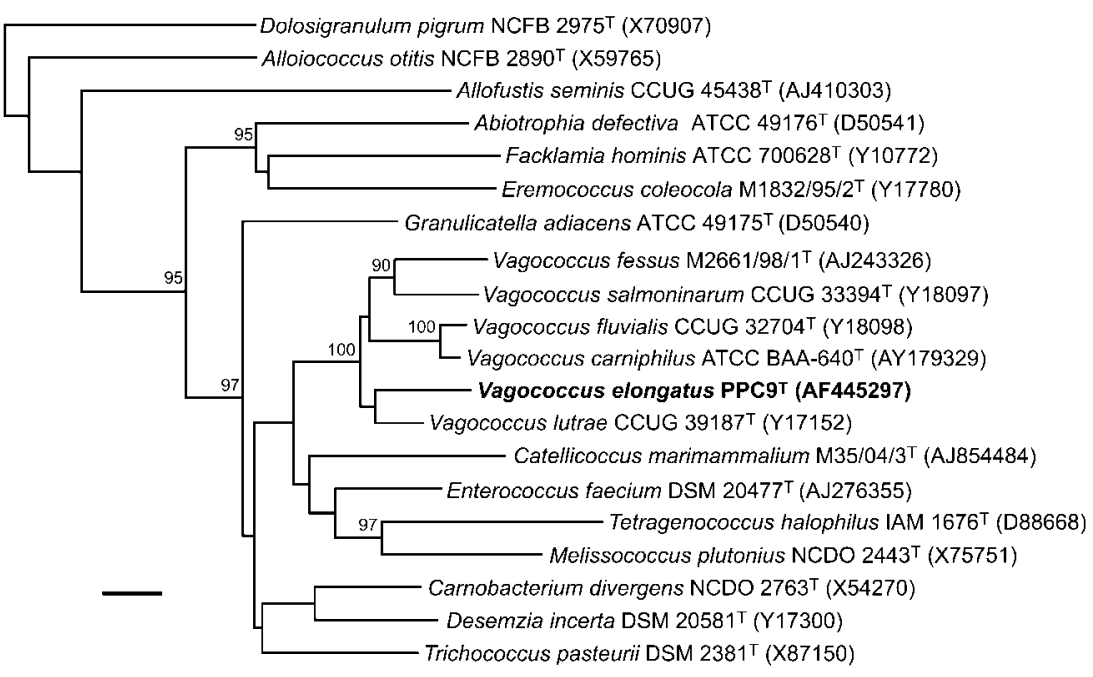

Fig. 1. Unrooted tree showing the phylogenetic relationships of strain $\mathrm{PPC}^{\top}$ and some other Gram-positive bacteria with low DNA $\mathrm{G}+\mathrm{C}$ content. The tree was constructed by using the neighbour-joining method based on a comparison of $16 \mathrm{~S}$ rRNA gene sequences of approximately $1320 \mathrm{nt}$. Bootstrap values, expressed as a percentage of 1000 replications, are given at branching points; only values $\geqslant 90 \%$ are shown. Bar, $1 \%$ sequence divergence. 
Table 1. Characteristics that differentiate strain $\mathrm{PPC}^{\top}$ from other Vagococcus species

Strains: 1, PPC9 ${ }^{\mathrm{T}}$; 2, V. carniphilus CCUG $32704^{\mathrm{T}} ; 3$, V. fessus CCUG $41755^{\mathrm{T}} ; 4$, V. fluvialis CCUG $32704^{\mathrm{T}} ; 5, \mathrm{~V}$. lutrae CCUG $39187^{\mathrm{T}} ; 6, \quad$ V. salmoninarum CCUG $33394^{\mathrm{T}}$. Data for reference strains were taken from the CCUG database (http://www.ccug.se). - , Negative; + , positive; $+{ }^{\mathrm{w}}$, weak reaction.

\begin{tabular}{|c|c|c|c|c|c|c|}
\hline Characteristic & 1 & 2 & 3 & 4 & 5 & 6 \\
\hline \multicolumn{7}{|l|}{ Acid from: } \\
\hline$\beta$-D-Glucopyranoside & - & + & - & - & + & - \\
\hline Cyclodextrin & - & + & - & + & + & - \\
\hline Mannose & - & - & - & + & - & - \\
\hline Ribose & - & + & - & + & + & - \\
\hline Sorbitol & - & - & - & $+{ }^{w}$ & + & - \\
\hline Trehalose & - & + & - & + & + & + \\
\hline \multicolumn{7}{|l|}{ Production of: } \\
\hline$N$-Acetyl- $\beta$-glucosaminidase & - & - & - & - & + & - \\
\hline$\alpha$-Chymotrypsin & - & - & + & $+{ }^{w}$ & + & + \\
\hline$\beta$-Glucosidase & $+{ }^{\mathrm{w}}$ & - & - & + & + & + \\
\hline$\alpha$-Galactosidase & + & - & - & - & + & - \\
\hline$\beta$-Mannosidase & - & - & - & $+{ }^{w}$ & + & - \\
\hline $\begin{array}{l}\text { Pyroglutamic acid } \\
\text { arylamidase }\end{array}$ & - & + & + & $+{ }^{w}$ & + & + \\
\hline
\end{tabular}

Vagococcus elongatus sp. nov. is proposed. Although only a single strain of $V$. elongatus is currently known, we consider that the formal description of this species, together with $16 \mathrm{~S}$ rRNA gene sequence data and biochemical criteria to aid its identification, will facilitate its recognition in routine laboratory investigations, thereby permitting the recovery of additional strains.

\section{Description of Vagococcus elongatus sp. nov.}

Vagococcus elongatus (e.lon.ga'tus. L. masc. part. adj. elongatus elongated, pertaining to the pronounced elongation of the cells).

Cells are Gram-positive cocci occurring singly or in short chains, with cells elongated in the direction of the chain, and some giving the appearance of short, fat rods. Facultatively anaerobic and catalase-negative. Non-haemolytic and nonmotile. Lactic acid but no gas is produced from glucose metabolism. No growth in broth containing $6.5 \% \mathrm{NaCl}$. No growth at 10 or $45^{\circ} \mathrm{C}$. Using the API ID32S system, $\alpha$ galactosidase, $\beta$-glucosidase (weak reaction) and glycyl tryptophan arylamidase are detected. Acid is not produced from $N$-acetyl- $\beta$-glucosaminidase, alkaline phosphatase, alanyl phenylalanine proline arylamidase, arginine dihydrolase, $\mathrm{D}$-arabitol, L-arabinose, cyclodextrin, $\beta$-glucuronidase, $\beta$-galactosidase, glycogen, lactose, maltose, mannitol, $\alpha$-mannosidase, melibiose, methyl $\beta$-D-glucopyranoside, melezitose, pyroglutamic acid arylamidase, pullulan, Draffinose, D-ribose, sorbitol, sucrose, tagatose, trehalose or urease. Using the API ZYM system, weak reactions are obtained for alkaline phosphatase, esterase C4 and esterase lipase C8. No activity is detected for acid phosphatase, naphthol-AS-BI-phosphohydrolase, $N$-acetyl$\beta$-glucosaminidase, $\alpha$-chymotrypsin, cystine arylamidase, $\alpha$-galactosidase, $\beta$-galactosidase, $\alpha$-glucosidase, $\beta$-glucosidase, $\beta$-glucuronidase, lipase (C14), leucine arylamidase, $\alpha$-mannosidase, $\alpha$-fucosidase, trypsin or valine arylamidase. Nitrate is not reduced. Voges-Proskauer test is negative. Aesculin is hydrolysed but hippurate and gelatin are not. The DNA G + C content is $44.5 \mathrm{~mol} \%$.

The type strain, PPC9 ${ }^{\mathrm{T}}\left(=\mathrm{CCUG} 51432^{\mathrm{T}}=\mathrm{NRRL}\right.$ B$\left.41357^{\mathrm{T}}\right)$, was isolated from a swine-manure storage pit. Habitat unknown.

\section{Acknowledgements}

We wish to acknowledge the excellent technical assistance of Rhonda Zeltwanger.

\section{References}

Bailey, W. R. \& Scott, E.G. (1974). Diagnostic Microbiology, 4th edn. St Louis, MO: C. V. Mosby.

Bryant, M. P. (1972). Commentary on the Hungate technique for culture of anaerobic bacteria. Am J Clin Nutr 25, 1324-1328.

Collins, M. D., Ash, C., Farrow, J. A. E., Wallbanks, S. \& Williams, A. M. (1989). 16S Ribosomal ribonucleic acid sequence analysis of lactococci and related taxa. Description of Vagococcus fluvialis gen. nov., sp. nov. J Appl Bacteriol 67, 453-460.

Hashimoto, H., Noborisaka, R. \& Yanagawa, R. (1974). Distribution of motile streptococci in faeces of man and animals and in river and sea water. Jpn J Bacteriol 29, 387-393.

Hespell, R. B., Wolf, R. \& Bothast, R. J. (1987). Fermentation of xylans by Butyrivibrio fibrisolvens and other ruminal bacteria. Appl Environ Microbiol 53, 2849-2853.

Hoyles, L., Lawson, P. A., Foster, G., Falsen, E., Ohlen, M., Grainger, J. M. \& Collins, M. D. (2000). Vagococcus fessus sp. nov., isolated from a seal and a harbour porpoise. Int J Syst Evol Microbiol 50, 1151-1154.

Johnson, J. L. (1994). Similarity analysis of DNAs. In Methods for General and Molecular Bacteriology, pp. 656-682. Edited by P. Gerhardt, R. G. E. Murray, W. A. Wood \& N. R. Krieg. Washington, DC: American Society for Microbiology.

Lawson, P. A., Foster, G., Falsen, E., Ohlen, M. \& Collins, M. D. (1999). Vagococcus lutrae sp. nov., isolated from the common otter (Lutra lutra). Int J Syst Bacteriol 49, 1251-1254.

Nicholas, K. B., Nicholas, H. B., Jr \& Deerfield, D. W., II (1997). GeneDoc: analysis and visualization of genetic variation. EMBnet News 4 (2), 1-4. http://www.embnet.org/download/embnetnews/ embnet_news_4_2.pdf

Page, R. D. M. (1996). TREEVIEW: an application to display phylogenetic trees on personal computers. Comput Appl Biosci 12, 357-358.

Pearson, W. R. \& Lipman, D. J. (1985). Rapid and sensitive protein similarity searches. Science 227, 1435-1441.

Pot, B., Devriese, L. A., Hommez, J., Miry, C., Vandemeulebroecke, K., Kersters, K. \& Haesebrouck, F. (1994). Characterization and identification of Vagococcus fluvialis strains isolated from domestic animals. J Appl Bacteriol 77, 362-369. 
Rasmussen, S. W. (2002). SEQtools, a software package for analysis of nucleotide and protein sequences. http://www.seqtools.dk

Saitou, N. \& Nei, M. (1987). The neighbor-joining method: a new method for reconstructing phylogenetic trees. Mol Biol Evol 4, 406-425.

Schmidtke, L. M. \& Carson, J. (1994). Characteristics of Vagococcus salmoninarum isolated from diseased salmonid fish. J Appl Bacteriol 77, 229-236.

Shewmaker, P. L., Steigerwalt, A. G., Morey, R. E., Carvalho Mda, G., Elliott, J. A., Joyce, K., Barrett, T. J., Teixeira, L. M. \& Facklam, R. R. (2004). Vagococcus carniphilus sp. nov., isolated from ground beef. Int J Syst Evol Microbiol 54, 1505-1510.
Stackebrandt, E. \& Goebel, B. M. (1994). Taxonomic note: a place for DNA-DNA reassociation and $16 \mathrm{~S}$ rDNA sequence analysis in the present species definition in bacteriology. Int J Syst Bacteriol 44, 846-849.

Teixeira, L. M., Carvalho, M. G. S., Merquior, V. L. C., Steigerwalt, A. G., Brenner, D. J. \& Facklam, R. R. (1997). Phenotypic and genotypic characterization of Vagococcus fluvialis, including strains isolated from human sources. J Clin Microbiol 35, 2778-2781.

Wallbanks, S., Martinez-Murcia, A. J., Fryer, J. L., Philips, B. A. \& Collins, M. D. (1990). $16 \mathrm{~S}$ rRNA sequence determination for members of the genus Carnobacterium and related lactic acid bacteria and description of Vagococcus salmoninarum sp. nov. Int J Syst Bacteriol 40, 224-230. 